\title{
THE IMPACT OF THE GENETICALLY MODIFIED CROP'S VALUE ON THE SUSTAINABILITY OF AN ECOSYSTEM'S BIOMASS
}

\author{
HUANG, W. L. \\ School of Finance and Trade, Wenzhou Business College, 325000 Wenzhou, PR China \\ e-mail: huangwl@wzbc.edu.cn
}

(Received $6^{\text {th }}$ Jun 2019; accepted $24^{\text {th }}$ Oct 2019)

\begin{abstract}
This study uses the discrete-time optimal control models and numerical simulations of different scenarios to explore the impact of Genetically Modified (GM) Crop' value on the sustainability of an ecosystem's biomass. The results indicate that profit-maximizing farmers and a welfare-maximizing government would plant GM crops regardless of whether the biomass of the ecosystem remains sustainable (the ecological or evolutionary loss of GM crops) or not. However, the slightest loss of biomass (ecological loss) caused by the ecological mechanism of GM crops, due to their evolution mechanism, may become significant (evolutionary loss). Furthermore, the sustainability problem of biomass would become more severe due to the impact on identity preservation, improvement in planting technology and biotechnology, and climate change. However, conservation activities may help solve this problem.

Keywords: genetically modified crop, bioeconomics, biodiversity, discrete-time optimal control model, the value of genetically modified crop
\end{abstract}

\section{Introduction}

A genetically modified (GM) crop is the fastest developing crop, and it is governed by many regulatory systems dictated by international groups and countries. The focus of these regulatory systems should be the economic or ecological values of GM crops; however, the existing literature does not discuss all the value categories of GM crops. Thus, this paper proposes a numerical approach to evaluate GM crops, which combines economic value, ecological loss and evolutionary loss (Mutuc et al., 2013; Bradshaw, 2016). Many countries have discussed the values of GM crops and pronounced their regulations, as the regulation of GM crops in Belgium focuses on authorizing their production, use, and distribution (economic value), and limiting the potential release of GM crops into non-GM crop fields (ecological loss). Brazil has established rules for the production and marketing of GM crops and their release into the environment. The production and sale of GM crops are subject to very restrictive rules in France, and French legislation focuses on the potential release of GM crops into the environment and on labeling requirements (The Law Library of Congress, 2014).

The economic value of GM crops is defined as the additional profit of a crop-mix (with non-GM and GM crops) compared to a non-GM crop. Many studies have proved that profit from GM crops is higher than that from non-GM crops, as the former has larger yields. This is after considering its sustainability, health, and other related issues (James, 2005; Jacobsen et al., 2013; Mutuc et al., 2013; Blahova et al., 2014; Brookes and Barfoot, 2015; The International Service for the Acquisition of Agri-biotech Applications, 2016). As Qaim and Zilberman (2003) show that the pest-resistant GM crops substantially reduces pest damage and increases yields. Klümper and Qaim (2014) found the adoption of GM crops has reduced chemical pesticide use by $37 \%$, increased crop yields and farmer profits by $22 \%$ and $68 \%$. 
The ecological and evolutionary loss of GM crops are defined as the negative value from the reduced biomass in the present and last stages of an evolutionary ecosystem with a crop-mix compared to a scenario with a non-GM crop. A GM crop negatively affects the biomass of ecosystems because it may increase the mortality of other species. The impact on this biomass by GM crops could follow the competition or predation of the evolution mechanism and produce an uncertain result of this biomass. The evolution mechanism consists of elements such as monoculture, mutation, natural selection, genetic drift, recombination, and gene flow. The United Nations (2010) and Jesse and Obrycki (2000) show that the promotion of superior breeds (e.g., a GM crop) can have side effects (Brock and Xepapadeas, 2003; Noailly, 2008).

We argue that the value of a GM crop could be the sum of its economic value and ecological and evolutionary loss. Therefore, this study will discuss these three perspectives through numerical simulations of discrete-time optimal control models on the biomass of an ecosystem with crop-mix and pest interactions. Moreover, the impact of identity preservation, the improvement in planting technology and biotechnology, and climate change on the value of GM crops and the biomass of an ecosystem would be discussed (Weitzman, 1998; Kouser and Qaim, 2013).

In short, the goal of this study is to analyze and simulate the effect of a GM crop' value on biomass sustainability. The remainder of this paper is organized as follows. In Section 2, we develop the Materials and Methods. The points are Farmer's GM crop management (FGM) Model and Government's GM crop Management (GGM) Model. In Section 3, we develop their results, the points are to perform the numerical simulations of FGM and GGM numerical simulations. The last two sections contain our discussions and concluding remarks.

\section{Materials and methods}

To develop an integrated valuation model of farmer's GM crop management, this study considered an ecosystem with crop-pest interactions, and this theoretical model should be adapted to many countries. The crops could be divided into GM, and non-GM crops, $\mathrm{i}=1,2$, and there was only one type of pests (Ives and Andow, 2002).

At time $t$, let $Q_{i, t}$ denote the farmer' $s$ harvest of crop $i, D_{i}\left(Q_{i, t}\right)$ and $S_{i}\left(Q_{i, t}\right)$ be the inverse demand and supply function of crop $\mathrm{i}$, so that the farm's revenue and cost function would be $R\left(Q_{1, t}, Q_{2, t}\right)=D_{1}\left(Q_{1, t}\right) Q_{1, t}+D_{2}\left(Q_{2, t}\right) Q_{2, t} \quad$, and $C\left(Q_{1, t}, Q_{2, t}\right)=$ $S_{1}\left(Q_{1, t}\right) Q_{1, t}+S_{2}\left(Q_{2, t}\right) Q_{2, t}$, respectively.

The objective of a representative farmer is to choose time paths $Q_{i, t}$ to maximize the farmer's profit function:

$$
\sum_{\mathrm{t}=1}^{\mathrm{T}} \rho^{\mathrm{t}}\left[\mathrm{D}_{1}\left(\mathrm{Q}_{1, \mathrm{t}}\right) \mathrm{Q}_{1, \mathrm{t}}+\mathrm{D}_{2}\left(\mathrm{Q}_{2, \mathrm{t}}\right) \mathrm{Q}_{2, \mathrm{t}}-\mathrm{S}_{1}\left(\mathrm{Q}_{1, \mathrm{t}}\right) \mathrm{Q}_{1, \mathrm{t}}+\mathrm{S}_{2}\left(\mathrm{Q}_{2, \mathrm{t}}\right) \mathrm{Q}_{2, \mathrm{t}}\right]
$$

The time $[0, T]$ is assumed fixed, and the discount factor is $\rho=(1+\eta)^{-1}$, where $\eta>0$ is the discount rate.

The biomass of this ecosystem $\left(B_{t}\right)$ is defined as the sum of the biomass of the crop and pest at time $t\left(B_{c, t}, B_{p, t}\right)$. In the existing literature, $B_{t}$ could be measured by its biodiversity from different hierarchical categories. World Resources Institute et al. (1992) 
divided biodiversity into three hierarchical categories: genetic diversity, species diversity, and ecosystem diversity (Vatn and Bromley, 1994; Mainwaring, 2001).

The amount of land for crop-mix is limited, and crops in the initial stage are all crop 2. The biomass of the ecosystem depends on the farmer's harvests of the crop-mix, and the growth and death rates of crop and pest. Biomass corresponds to the quantity of crop 2, based on the assumption that the genetic makeup of every individual in crop 1 is the same. Although GM crops can be planted in higher densities than conventional crops, for the sake of simplicity, this study does not consider this situation (Stanger and Lauer, 2006).

Based on the above assumptions, as in Brock and Xepapadeas (2003), the biomass evolution of the crop, pest, and ecosystem could be characterized as follow:

$$
\begin{gathered}
\mathrm{B}_{\mathrm{c}, \mathrm{t}}-\mathrm{B}_{\mathrm{c}, \mathrm{t}-1}=\left(\mathrm{B}_{\mathrm{c}, \mathrm{t}-1}-\mathrm{Q}_{1, \mathrm{t}}^{*}\right)\left(\mathrm{g}_{\mathrm{c}} \mathrm{p}_{\mathrm{c}, \mathrm{t}-1}-\mathrm{m}_{\mathrm{c}} \mathrm{p}_{\mathrm{p}, \mathrm{t}-1}\right)-\mathrm{Q}_{1, \mathrm{t}}^{*}-\mathrm{Q}_{2, \mathrm{t}}^{*} \\
\mathrm{~B}_{\mathrm{c}, \mathrm{t}=0}=\mathrm{B}_{\mathrm{c}, 0} \\
\mathrm{t}=1, \ldots \mathrm{T} \\
\mathrm{B}_{\mathrm{p}, \mathrm{t}}-\mathrm{B}_{\mathrm{p}, \mathrm{t}-1}=\mathrm{B}_{\mathrm{p}, \mathrm{t}-1}\left[\mathrm{~g}_{\mathrm{p}} \mathrm{p}_{\mathrm{p}, \mathrm{t}-1}-\mathrm{m}_{\mathrm{p}}\left(\mathrm{p}_{\mathrm{c}, \mathrm{t}-1}\right)^{-1}\right] \\
\mathrm{B}_{\mathrm{p}, \mathrm{t}=0}=\mathrm{B}_{\mathrm{p}, 0} \\
\mathrm{t}=1, \ldots \mathrm{T}
\end{gathered}
$$

where:

$$
\begin{gathered}
\mathrm{p}_{\mathrm{c}, \mathrm{t}}=\mathrm{B}_{\mathrm{c}, \mathrm{t}}\left(\mathrm{B}_{\mathrm{c}, 0}\right)^{-1}, \mathrm{p}_{\mathrm{p}, \mathrm{t}}=\mathrm{B}_{\mathrm{p}, \mathrm{t}}\left(\mathrm{B}_{\mathrm{p}, 0}\right)^{-1} \\
\mathrm{~B}_{\mathrm{t}}=\mathrm{B}_{\mathrm{c}, \mathrm{t}}+\mathrm{B}_{\mathrm{p}, \mathrm{t}} \\
\mathrm{t}=1, \ldots \mathrm{T} \\
B_{t}-B_{t-1}=\left(B_{c, t-1}-Q_{1, t}^{*}\right)\left(g_{c} p_{c, t-1}-m_{c} p_{p, t-1}\right) \\
+B_{p, t-1}\left[g_{p} p_{p, t-1}-m_{p}\left(p_{c, t-1}\right)^{-1}\right]-Q_{1, t}^{*}-Q_{2, t}^{*} \\
\mathrm{~B}_{\mathrm{t}=0}=\mathrm{B}_{\mathrm{c}, 0}+\mathrm{B}_{\mathrm{p}, 0}
\end{gathered}
$$

where $g_{c}, g_{p}, m_{c}$ and $m_{p}$ are the constant growth and death rates of the crop and pest. The pest biomass is exogenously assumed to be negatively related to the quantity of the GM crop.

For numerical simulations of the above model, this study assumes $D_{1}\left(Q_{1, t}\right)=P_{1}$, $\mathrm{D}_{2}\left(\mathrm{Q}_{2, \mathrm{t}}\right)=\mathrm{P}_{2}, \mathrm{~S}_{1}\left(\mathrm{Q}_{1, \mathrm{t}}\right)=\alpha+\beta \mathrm{Q}_{1, \mathrm{t}}, \mathrm{S}_{2}\left(\mathrm{Q}_{2, \mathrm{t}}\right)=\alpha+\gamma \mathrm{Q}_{2, \mathrm{t}}$, and $\gamma>\beta>0$. The optimal harvest quantity of crop 1 and crop 2 at time $t\left(Q_{1, t}^{*}, Q_{2, t}^{*}\right)$ are derived from Equation (1), which are $Q_{1, t}^{*}=\left(P_{1}-\alpha\right)(2 \beta)^{-1}$ and $Q_{2, t}^{*}=\left(P_{2}-\alpha\right)(2 \gamma)^{-1}$. These equations are used in combination with the growth Equation (5) of the ecosystem's biomass to obtain a measure of biomass in time $[0, \mathrm{~T}]$.

Moreover, this study uses the GGM model which assess the value of biomass to discuss the economic, ecological, and evolutionary value of GM crops. In the GGM model, the welfare function on the biomass of an ecosystem is defined as $W\left(B_{t}\right)=$ $W\left(B_{c, t}, B_{p, t}\right)$. The social welfare function of the government is defined as follows: 


$$
\begin{gathered}
\sum_{\mathrm{t}=1}^{\mathrm{T}} \rho^{\mathrm{t}-1}\left[\int_{0}^{\mathrm{Q}_{1, \mathrm{t}}} \mathrm{D}_{1}(\mathrm{x}) \mathrm{dx}+\int_{0}^{\mathrm{Q}_{2, \mathrm{t}}} \mathrm{D}_{2}(\mathrm{x}) \mathrm{dx}+\mathrm{W}\left(\mathrm{B}_{\mathrm{t}-1}\right)\right. \\
-\int_{0}^{\mathrm{Q}_{1, \mathrm{t}}} \mathrm{S}_{1}(\mathrm{x}) \mathrm{dx}-\int_{0}^{\mathrm{Q}_{2, \mathrm{t}}} \mathrm{S}_{2}(\mathrm{x}) \mathrm{dx} \\
-\mathrm{D}_{1}\left(\mathrm{Q}_{1, \mathrm{t}}\right) \mathrm{Q}_{1, \mathrm{t}}-\mathrm{D}_{2}\left(\mathrm{Q}_{2, \mathrm{t}}\right) \mathrm{Q}_{2, \mathrm{t}}+\mathrm{S}_{1}\left(\mathrm{Q}_{1, \mathrm{t}}\right) \mathrm{Q}_{1, \mathrm{t}}+\mathrm{S}_{2}\left(\mathrm{Q}_{2, \mathrm{t}}\right) \mathrm{Q}_{2, \mathrm{t}}
\end{gathered}
$$

This study uses the Bellman state valuation function as a welfare measure of biomass, and it assumes that the welfare function in $t$ is affected by the ecosystem's biomass in $t-1$. Brock and Xepapadeas (2003) obtained an endogenous measure (Bellman state valuation function) of the biomass' value, which is linked to ecologically/biologically oriented biomass metrics. There are more than 100 empirical papers that positively evaluate the biodiversity of indigenous cattle, threatened mammals, native plants, forests, wetlands, marine sanctuaries, ecosystems (Martin-Lopez et al., 2007; Matero and Saastamoinen, 2007; Siikamaki and Layton, 2007; Baral et al., 2008; Garcia et al., 2009; Yi et al., 2014). Many studies argue that the value of biodiversity includes the market value (a source of new industrial, agricultural, or pharmaceutical products) and non-market value (option, existence, and bequest values, culture and spiritual), as in Weitzman (1998), Polasky and Solow (1995), Nehring and Puppe (2002), and Brock and Xepapadeas (2003).

The purpose of the government is to maximize social welfare function, and the present value of the social welfare function at time $t$ is $V\left(B_{t-1}, C_{t}\right)$. Let $B S_{t-1}=\left(B_{c, t-1}, B_{p, t-1}\right)$, $C_{t}=\left(Q_{1, t}, Q_{2, t}\right)$ be the state and control vector associated with the maximization of (6), and $\mathrm{f}\left(\mathrm{BS}_{\mathrm{t}-1}, \mathrm{C}_{\mathrm{t}}\right)$ be the vector of (5). The Hamiltonian function is as follows:

$$
H_{c}\left(B S_{t-1}, C_{t}\right)=V\left(B S_{t-1}, C_{t}\right)+\rho \lambda_{p, t+1} f_{p}\left(B S_{t-1}, C_{t}\right),
$$

For the sake of simplicity and comparability, we follow the assumptions in Section 2: $\mathrm{W}\left(\mathrm{B}_{\mathrm{t}}\right)=\mathrm{W}\left(\mathrm{BS}_{\mathrm{t}}\right)=\delta\left(\mathrm{B}_{\mathrm{c}, \mathrm{t}}+\mathrm{B}_{\mathrm{p}, \mathrm{t}}\right)$, and $\delta$ is a constant value for a unit of biomass.

As the optimality conditions of the Hamiltonian function derived from (2), (3), (4) and (6) are self-referred, $\left(B_{c, t}, B_{p, t}\right)$ could not be simulated by repeating the process. Thus, the assumptions of (2) and (3) are modified as:

$$
\begin{array}{cl}
B_{c, t}-B_{c, t}-1=\left(B_{c, t-1}-Q_{1, t}^{*}\right)-Q_{1, t}^{*}-Q_{2, t}^{*}, B_{c, t=0}=B_{c, 0}, & t=1, \ldots T, \\
B_{p, t}-B_{p, t-1}=B_{p, t-1}\left(g_{p}-m_{p}\right), \quad B_{p, t=0}=B_{p, 0}, & t=1, \ldots T,
\end{array}
$$

The Hamiltonian function is:

$$
\begin{gathered}
\mathrm{H}_{\mathrm{c}}\left(\mathrm{BS}_{\mathrm{t}-1}, \mathrm{C}_{\mathrm{t}}\right)=P_{1} Q_{1, t}+P_{2} Q_{2, t}+\delta\left(B_{c, t-1}+B_{p, t-1}\right)-\alpha Q_{1, t}-\beta Q_{1, t}^{2}-\alpha Q_{2, t}-\gamma Q_{2, t}^{2} \\
+\rho \lambda_{\mathrm{c}, \mathrm{t}+1}\left[\left(\mathrm{~B}_{\mathrm{c}, \mathrm{t}-1}-\mathrm{Q}_{1, \mathrm{t}}\right)\left(\mathrm{g}_{\mathrm{c}}-\mathrm{m}_{\mathrm{c}}\right)-\mathrm{Q}_{1, \mathrm{t}}-\mathrm{Q}_{2, \mathrm{t}}\right]+\rho \lambda_{\mathrm{p}, \mathrm{t}+1} \mathrm{~B}_{\mathrm{p}, \mathrm{t}-1}\left(\mathrm{~g}_{\mathrm{p}}-\mathrm{m}_{\mathrm{p}}\right),
\end{gathered}
$$

with the optimality conditions:

$$
\begin{gathered}
\partial H_{c} / \partial Q_{1, t}=P_{1}-\alpha-2 \beta Q_{1, t}-\rho \lambda_{c, t+1}\left(1+\mathrm{g}_{\mathrm{c}}-\mathrm{m}_{\mathrm{c}}\right)=0, \mathrm{t}=1, \ldots \mathrm{T}, \\
\partial H_{c} / \partial Q_{2, t}=P_{2}-\alpha-2 \gamma Q_{2, t}-\rho \lambda_{c, t+1}=0, \mathrm{t}=1, \ldots \mathrm{T}
\end{gathered}
$$




$$
\begin{gathered}
\rho\left(\lambda_{\mathrm{c}, \mathrm{t}+1}-\lambda_{\mathrm{c}, \mathrm{t}}\right)=-\partial \mathrm{H}_{\mathrm{c}} / \partial \mathrm{B}_{\mathrm{c}, \mathrm{t}-1}=\rho \lambda_{\mathrm{c}, \mathrm{t}+1}\left(\mathrm{~g}_{\mathrm{c}}-\mathrm{m}_{\mathrm{c}}\right)-\delta, \mathrm{t}=1, \ldots \mathrm{T}, \\
\left.\rho\left(\lambda_{p, t+1}-\lambda_{p, t}\right)=-\partial H_{c} / \partial B_{p, t-1}=\rho \lambda_{\mathrm{p}, \mathrm{t}+1}\left(\mathrm{~g}_{\mathrm{p}}-\mathrm{m}_{\mathrm{p}}\right)-\delta, \mathrm{t}=1, \ldots \mathrm{T}\right) \\
\lambda_{\mathrm{c}, \mathrm{T}+1}=\lambda_{\mathrm{p}, \mathrm{T}+1}=0 \\
B_{c, t}-B_{c, t-1}=\rho^{-1} \partial H_{c} / \partial \lambda_{c, t-1}=\left(\mathrm{B}_{c, t-1}-Q_{1, t}\right)\left(\mathrm{g}_{\mathrm{c}}-\mathrm{m}_{\mathrm{c}}\right)-Q_{1, t}- \\
Q_{2, t}, \\
\mathrm{t}=1, \ldots \mathrm{T}
\end{gathered}
$$

To derive all the necessary information, the process begins in the final period $(T=20$, in this case) and proceeds backward. From (7) and (8), the optimal harvest quantity of the $\mathrm{GM}$ crop and non-GM crop at time $\mathrm{t}\left(\mathrm{Q}_{1, \mathrm{t}}^{* *}, \mathrm{Q}_{2, \mathrm{t}}^{* *}\right)$ are $\left[\mathrm{P}_{1}-\alpha-\rho \lambda_{c, t+1}\left(1+\mathrm{g}_{\mathrm{c}}-\mathrm{m}_{\mathrm{c}}\right)\right] /(2 \beta)$ and $\left(\mathrm{P}_{2}-\alpha-\rho \lambda_{\mathrm{c}, \mathrm{t}+1}\right) /(2 \gamma)$, respectively. Since $\lambda_{c, 21}=\lambda_{p, 21}=0$, (9) is used to solve $\lambda_{c, 20}=\lambda_{p, 20}=\delta / \rho$. The process is repeated and $\left(\mathrm{B}_{\mathrm{c}, \mathrm{t}}, \mathrm{B}_{\mathrm{p}, \mathrm{t}}\right)$ is derived.

\section{Results}

Table 1 reports the values of the parameters obtained through the FGM model. We consider six cases to study the value of GM crops and the biomass of the ecosystem in time [0, 20]. The parameters in Tables 1 and 3 are set as the existing literature, and the minor modification of the assumptions in the FGM and GGM model does not affect the findings of this study as many simulation results have been obtained from various parameter values. Many studies have discussed the higher price of the non-GM crop in Case 2. Lusk et al. (2001) and Chern et al. (2003) discussed consumer acceptance and willingness to pay for the non-GM crop. Many studies have also discussed the lower fixed cost of the two crops in Case 3, such as Marra et al. (2003). Raymond Park et al. (2010) examine the lower variable cost of GM crops in Case 4. McDowell et al. (2011) discussed the lower growth rate and higher death rate of the two crops in Case 5 and Case 6.

Case 0 is the initial scenario with Crop 2, and Case 1 is used as the baseline for the crop-mix. In Case 2, the non-GM crop is segregated by identity preservation and has a higher price. Case 3 is characterized by a lower fixed cost of the two crops for the improvement of planting technology, and Case 4 by the lower variable cost of GM crops for the improvement of biotechnology. Case 5 and Case 6 are characterized by the lower growth rate and higher death rate of the two crops due to climate change. Crop 1 and Crop 2 sell at the same price in all cases (except Case 2, for identity preservation), as in most cases, it is hard to distinguish GM crops from non-GM crops. 
The solutions of Cases $0 \sim 6$ are reported in Table 2 and Figure 1. Our main conclusions on the value of the GM crop are as follows. First, the value of the GM crop is equal to its economic value in the FGM model, as farmers do not consider the value of biomass. Second, profit-maximizing farmers are likely to plant more GM crops than nonGM crops, as the value of GM crops is higher. Third, the improvement of planting technology and biotechnology increases the value of GM crops. Moreover, identity preservation and climate change do not affect the value of GM crops. These conclusions are in line with Brookes and Barfoot (2015), James (2005) and The International Service for the Acquisition of Agri-biotech Applications (2016).

Table 1. Values of the Parameters obtained with the FGM Model

\begin{tabular}{l|c|c|c|c|c|c|c|c|c}
\hline & $\mathbf{P}_{\mathbf{1}}$ & $\mathbf{P}_{\mathbf{2}}$ & $\boldsymbol{\alpha}$ & $\boldsymbol{\beta}$ & $\boldsymbol{\gamma}$ & $\mathbf{G}$ & $\mathbf{M}$ & $\mathbf{B}_{\mathbf{0}}$ & $\boldsymbol{\eta}$ \\
\hline Case 0 & 0 & 5.00 & 1.00 & 0 & 0.04 & 0.04 & 0.02 & $10,000.00$ & 0.05 \\
Case 1 & 5.00 & 5.00 & 1.00 & 0.02 & 0.04 & 0.04 & 0.02 & $10,000.00$ & 0.05 \\
Case 2 & 5.00 & 6.00 & 1.00 & 0.02 & 0.04 & 0.04 & 0.02 & $10,000.00$ & 0.05 \\
Case 3 & 5.00 & 5.00 & 0.50 & 0.02 & 0.04 & 0.04 & 0.02 & $10,000.00$ & 0.05 \\
Case 4 & 5.00 & 5.00 & 1.00 & 0.01 & 0.04 & 0.04 & 0.02 & $10,000.00$ & 0.05 \\
Case 5 & 5.00 & 5.00 & 1.00 & 0.02 & 0.04 & 0.02 & 0.02 & $10,000.00$ & 0.05 \\
Case 6 & 5.00 & 5.00 & 1.00 & 0.02 & 0.04 & 0.04 & 0.04 & $10,000.00$ & 0.05 \\
\hline
\end{tabular}

Note: these results are based on simulated data

Table 2. Simulation using the FGM Model

\begin{tabular}{c|c|c|c|c|c}
\hline & \multirow{2}{*}{ The value of GM crop } & \multicolumn{2}{c}{ The value of non-GM crop } & \multicolumn{2}{c}{ The biodiversity at T=20 } \\
\cline { 5 - 6 } & 0 & $1,308.53$ & $6,891.52$ & $5,631.04$ & $12,522.56$ \\
Case 0 & $2,617.06$ & $1,308.54$ & $3,320.71$ & $4,211.80$ & $7,532.51$ \\
Case 1 & $2,617.06$ & $2,044.59$ & $2,951.07$ & $3,993.74$ & $6,944.80$ \\
Case 2 & $3,312.22$ & $1,656.11$ & $2,765.40$ & $3,875.60$ & $6,641.01$ \\
Case 3 & $5,234.13$ & $1,308.53$ & 629.45 & $1,785.07$ & $2,414.52$ \\
Case 4 & $2,617.06$ & $1,308.54$ & $1,954.48$ & $1,968.84$ & $3,923.32$ \\
Case 5 & $2,617.06$ & $1,308.54$ & $2,433.38$ & 759.69 & $3,193.08$ \\
Case 6 & $2,716.37$ & $1,463.34$ & $2,992.29$ & $3,175.11$ & $6,167.40$ \\
Mean & & & & & \\
\hline
\end{tabular}

Note: these results are based on simulated data

Furthermore, our main conclusions about the impact of the introduction of a GM crop on the biomass of an ecosystem are as follow. First, the biomass of an ecosystem is decreased by the introduction of a GM crop. Second, the impact on the biomass of an ecosystem caused by a GM crop in the initial stage might be negligible, but even the slightest change could follow the evolution mechanism and lead to a considerable loss of an ecosystem's biomass. Third, climate change and the improvement in planting technology and biotechnology would decrease the biomass of an ecosystem. Fourth, the biomass of an ecosystem would not be improved and may even be worsened by identity preservation. These conclusions mean the sustainability of an ecosystem's biomass might not exist by the impact of the GM crop's economic value and are in line with Gregory et al. (2009), and the United Nations (2010). 


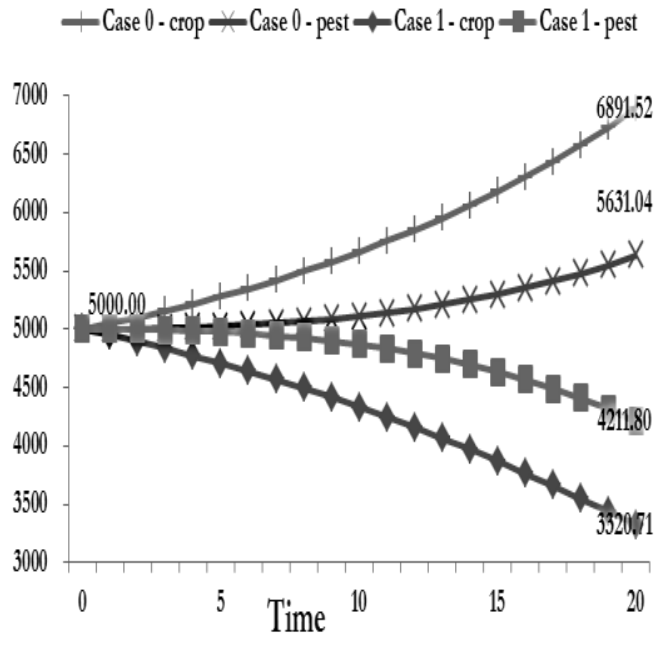

(a) Case 0 vs. Case 1

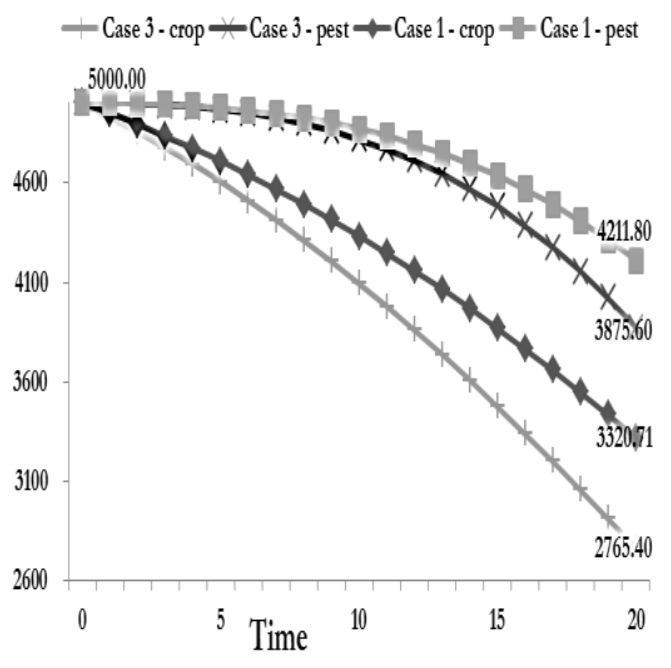

(c) Case 3 vs. Case 1

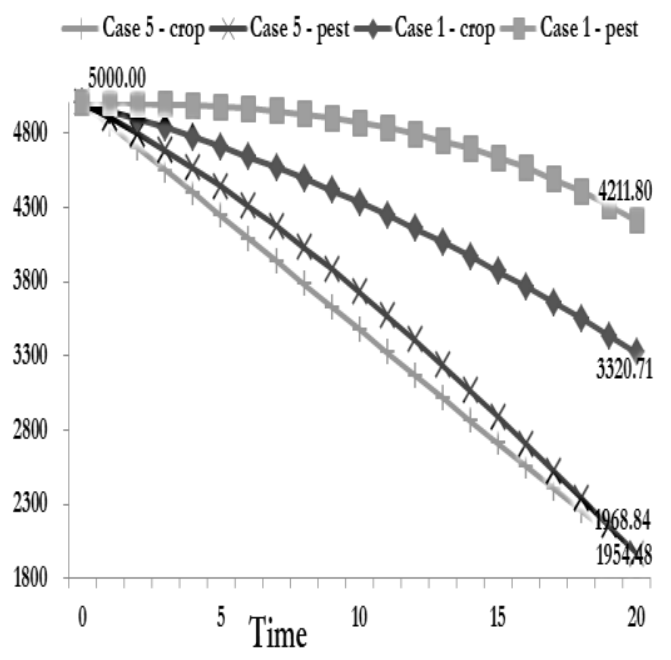

(e) Case 5 vs. Case 1

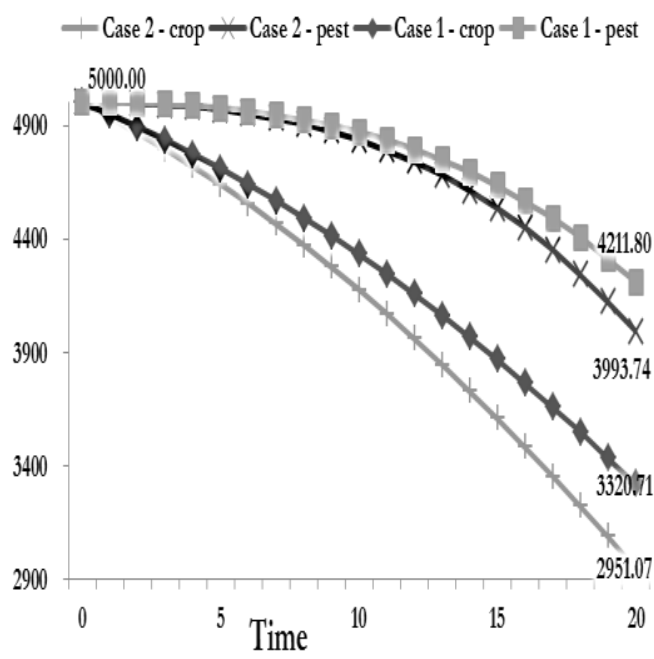

(b) Case 2 vs. Case 1

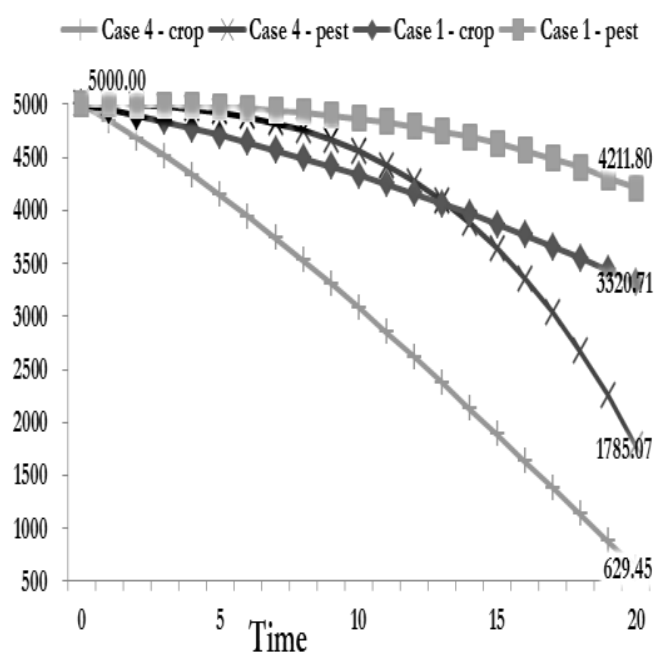

(d) Case 4 vs. Case 1

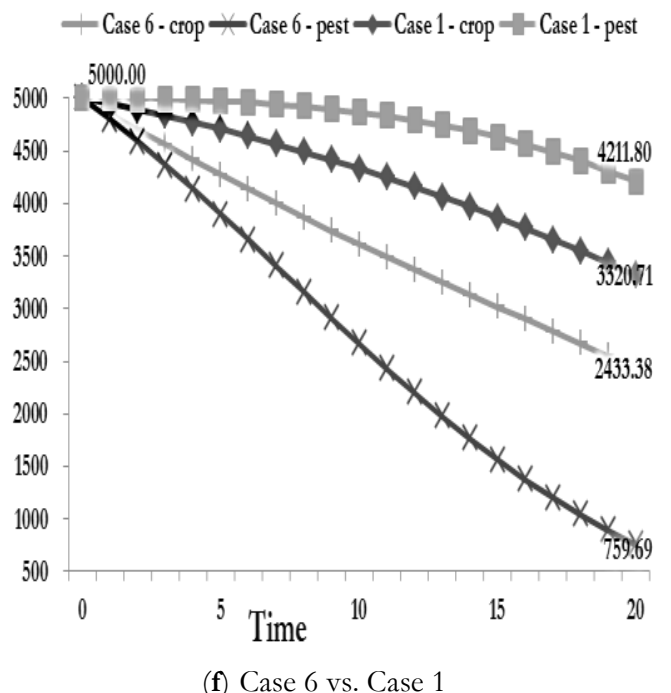

Figure 1. The biodiversity of crop and pest at $t=0 \sim 20$ for (a) Case 0 vs. Case 1, (b) Case 2 vs. Case 1, (c) Case 3 vs. Case 1, (d) Case 4 vs. Case 1, (e) Case 5 vs. Case 1, and (f) Case 6 vs. 
Table 3 reports the values of the parameters obtained through the GGM model. This study uses these cases to study the value of the GM crop, welfare, and the biomass in the GGM model. A non-GM crop characterizes Case 7, and Case 8 uses a crop-mix to discuss its effect of the increment of $\mathrm{P}_{2}$ (Case 9), $\alpha$ (Case 10), $\beta$ (Case 11), $\mathrm{M}$ (Case 13), $\delta$ (Case 14), and the decrement of $\mathrm{G}$ (Case 12). Case 14 can be explained by the growing recognition and activities of the public and private sector to conserve biomass (Bishop et al., 2008). A discount rate of 5 percent means that the discount factor $(\rho)$ is about 0.95 .

Table 3. Values of the Parameters with the government's bit-crop management model

\begin{tabular}{l|c|c|c|c|c|c|c|c|c|c}
\hline & $\mathbf{P}_{\mathbf{1}}$ & $\mathbf{P}_{\mathbf{2}}$ & $\boldsymbol{\alpha}$ & $\boldsymbol{\beta}$ & $\boldsymbol{\gamma}$ & $\mathbf{G}$ & $\mathbf{M}$ & $\boldsymbol{\delta}$ & $\boldsymbol{\eta}$ & $\mathbf{B}_{\mathbf{0}}$ \\
\hline Case 7 & 0.00 & 5.00 & 1.00 & 0.00 & 0.04 & 0.04 & 0.02 & 1.00 & 0.05 & $10,000.00$ \\
Case 8 & 5.00 & 5.00 & 1.00 & 0.02 & 0.04 & 0.04 & 0.02 & 1.00 & 0.05 & $10,000.00$ \\
Case 9 & 5.00 & 6.00 & 1.00 & 0.02 & 0.04 & 0.04 & 0.02 & 1.00 & 0.05 & $10,000.00$ \\
Case 10 & 5.00 & 5.00 & 0.50 & 0.02 & 0.04 & 0.04 & 0.02 & 1.00 & 0.05 & $10,000.00$ \\
Case 11 & 5.00 & 5.00 & 1.00 & 0.01 & 0.04 & 0.04 & 0.02 & 1.00 & 0.05 & $10,000.00$ \\
Case 12 & 5.00 & 5.00 & 1.00 & 0.02 & 0.04 & 0.02 & 0.02 & 1.00 & 0.05 & $10,000.00$ \\
Case 13 & 5.00 & 5.00 & 1.00 & 0.02 & 0.04 & 0.04 & 0.04 & 1.00 & 0.05 & $10,000.00$ \\
Case 14 & 5.00 & 5.00 & 1.00 & 0.02 & 0.04 & 0.04 & 0.02 & 2.00 & 0.05 & $10,000.00$ \\
\hline
\end{tabular}

Note: these results are based on simulated data

The value of biomass is set far below the price of GM crops. The reason for this is that people's willingness to pay for conserving the biomass is lower than its market value. The solutions of Cases 7 14 are reported in Table 4, Table 5, and Figure 2.

Table 4. Simulation of welfare and biodiversity in the GGM model

\begin{tabular}{c|c|c}
\hline & The present value of Welfare & The biodiversity of the ecosystem in T=20 \\
\hline Case 7 & $2,791.33$ & $13,671.94$ \\
Case 8 & $5,176.34$ & 8820.74 \\
Case 9 & $5,897.93$ & $8,517.03$ \\
Case 10 & $6,197.10$ & $8,359.09$ \\
Case 11 & $7,677.02$ & $6,399.28$ \\
Case 12 & $4,987.48$ & $5,409.29$ \\
Case 13 & $4,912.35$ & $4,281.26$ \\
Case 14 & $6,431.81$ & $8,904.95$ \\
Mean & $5,494.46$ & $7,741.73$ \\
\hline
\end{tabular}

Note: these results are based on simulated data

Our main conclusions on the social welfare and value of GM crops are as follows. First, a welfare-maximizing government is likely to plant more GM crops than non-GM crops, as the welfare associated with GM crops is higher than that of non-GM crops. Second, identity preservation, improvement in planting technology and biotechnology, and biomass conservation activities could improve social welfare, but climate change could not. Third, the improvement in planting technology and biotechnology and biomass 
conservation activities could improve the value of GM crops, but identity preservation and biomass conservation activities could not. Finally, the impact of climate change on the value of GM crops depends on the ability of species to migrate or cope with new scenarios.

Our conclusions about the impact of the introduction of a GM crop on the biomass of an ecosystem are as follows. First, the approaches of simulated biomass in each case of the GGM and FGM models are similar, the conclusions are in line with the solutions of the FGM model, and the modification of the assumptions in the GGM model does not affect the findings of this paper. Second, biomass conservation activities slow down the decline rate of biomass. These conclusions imply the sustainability of an ecosystem's biomass might not exist by the impact of the GM crop's economic value considering its ecological or evolutionary loss.

Table 5. Simulation of the Value of GM crop in the GGM Model

\begin{tabular}{c|c|c|c|c}
\hline & $\begin{array}{c}\text { The economic value of } \\
\text { GM crop (B) }\end{array}$ & $\begin{array}{c}\text { The ecological value of } \\
\text { GM crop (C) }\end{array}$ & $\begin{array}{c}\text { The evolutionary value of } \\
\text { GM crop (D=A-B-C) }\end{array}$ & $\begin{array}{c}\text { The value of GM } \\
\text { crop (A) }\end{array}$ \\
\hline Case 7 & 0.00 & 0.00 & 0.00 & 0.00 \\
Case 8 & $2,615.07$ & -12.76 & -217.30 & $2,385.01$ \\
Case 9 & $2,615.07$ & -12.76 & -217.30 & $2,385.01$ \\
Case 10 & $3,310.22$ & -14.39 & -230.41 & $3,065.42$ \\
Case 11 & $5,230.13$ & -25.52 & -318.93 & $4,885.69$ \\
Case 12 & $2,614.53$ & -12.72 & -180.17 & $2,421.64$ \\
Case 13 & $2,614.53$ & -12.72 & -255.30 & $2,346.51$ \\
Case 14 & $2,609.08$ & -24.87 & -428.06 & $2,156.15$ \\
Mean & $2,701.08$ & -14.47 & -230.93 & $2,455.68$ \\
\hline
\end{tabular}

Note: these results are based on simulated data

The simulated value of GM crops in previous studies (e.g., FGM model solution) is more significant than that in this study (e.g., GGM model solution), as the ecological and evolutionary loss of GM crops would decrease the optimal planned harvest of the welfaremaximizing government. Thus, the legal restrictions should consider the ecological and evolutionary loss of GM crops. Owing to public hostility and legal restrictions, no GM crops are currently planted in France (The Law Library of Congress, 2014). Based on the findings of FGM model are in line with previous studies, the differences between the presented approach and the referred literature are: 1. Their methods are different: the method of this paper is to use the numerical calculus and derivation of the hypothetic theory model which is the optimal control models with crop-mix and pest interactions, and the methods of the referred literature are most the statistical analysis of the different empirical models. 2. Their influencing factors are different: their influencing factors which discussed by this paper are identity preservation, improvement in planting technology and biotechnology, and climate change; their influencing factors of the referred literature are most the developing degree of country. As Klümper and Qaim (2014) use meta-analysis to prove that yield and profit gains for farmers of GM crops are higher in developing countries than those in developed countries. 


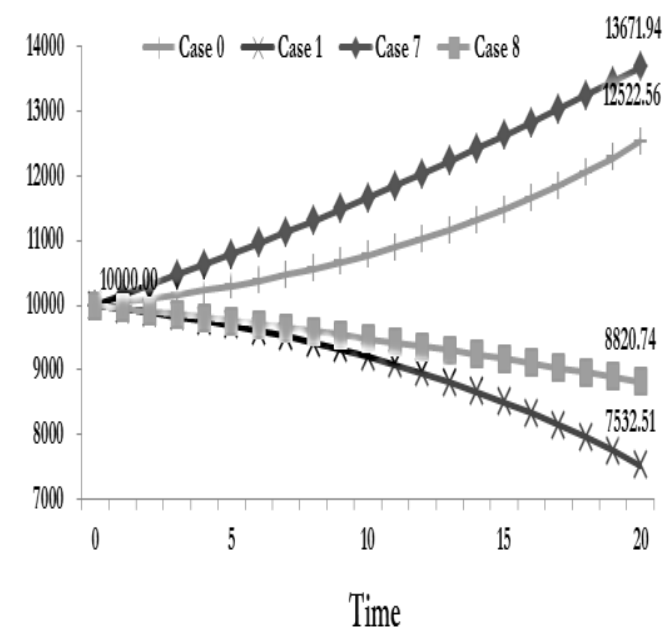

(a) Case 0 and Case 1 vs. Case 7 and Case 8

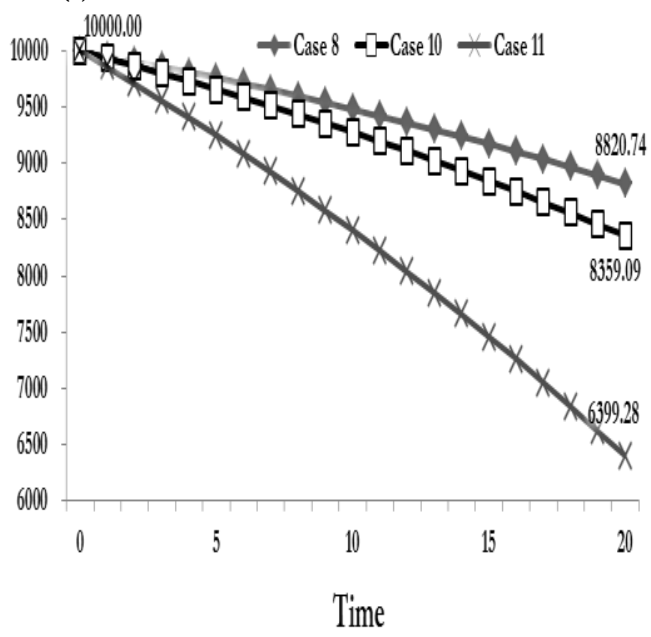

(c) Case 10 and Case 11 vs. Case 8

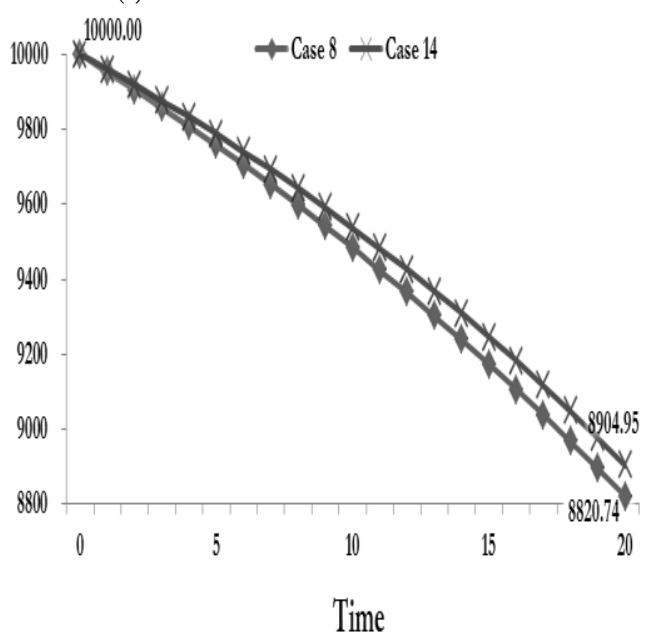

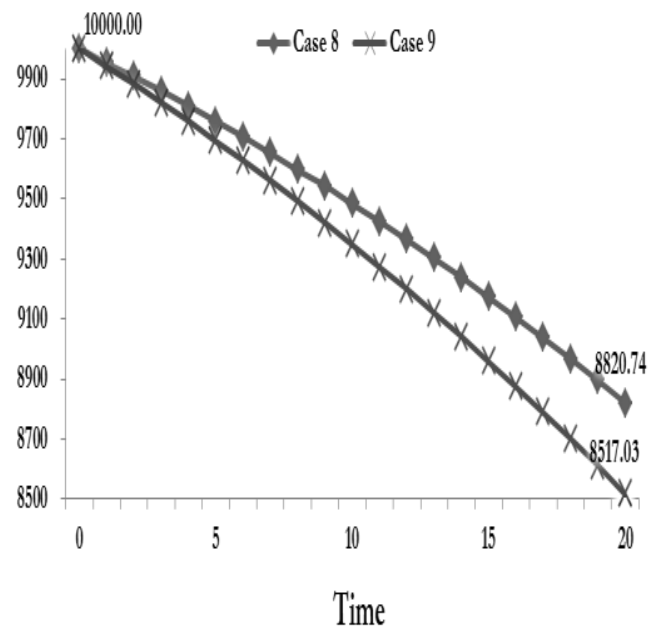

(b) Case 9 vs. Case 8

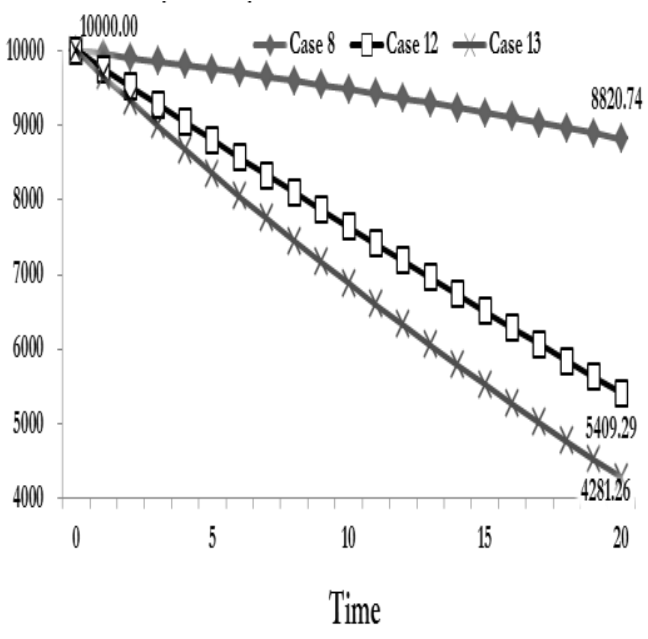

(d) Case 12 and Case 13 vs. Case 8

(e) Case 14 vs. Case 8

Figure 2. The biodiversity of the ecosystem at $t=0 \sim 20$ for (a) Case 0 and Case $1 \mathrm{vs}$. Case 7 and Case 8, (b) Case 9 vs. Case 8, (c) Case 10 and Case 11 vs. Case 8, (d) Case 12 and Case 13 vs. Case 8, and (e) Case 14 vs. Case 8 


\section{Discussion}

The major contributions of this study are as follows. First, this paper discussed the economic value and ecological and evolutionary loss of GM crops in agricultural systems simultaneously. Most existing studies discuss the economic value of GM crops as Klümper and Quaim (2014). Some studies discuss the ecological loss of GM crops as in Sanvido et al. (2007). Moreover, the only study discussing the evolutionary loss of GM crops is Flynn et al. (2010).

Second, this paper employs a discrete-time optimal control model and its numerical simulations to discuss the value of GM crops. We have not seen much research discussing the value of GM crops by the economic model and its numerical simulations. Therefore, this paper could increase the completeness of the theory on the value of GM crops. Third, this paper found that ecological loss of GM crops would be due to the mortality of its natural enemies, its monoculture, and competition with non-GM crops. The ecological loss of GM crops, which is the mortality of its natural enemies affected by GM crops, has been discussed in many previous studies. This paper also develops the ecological effect of GM crops to its monoculture and competition with non-GM crops. For the value of biodiversity is underestimated, government subsidies and fines for bioconservation are far below the market value of biology. As Chan et al. (1995) reported, the fine for illegal hunting is USD 50 (Kalmykia) and USD 60 (Kazakhstan) for one male Saiga antelope. However, the antelope can be sold at USD 764 (Hong Kong), USD 885 (Mainland China) and USD 920 (Taiwan) per kilogram.

Jose et al. (2006) studied the economic impact of GM crop in the Philippines by a Cobb-Douglas production function and a two-step econometric procedure where the initial stage consists of GM crop adoption decision and the second stage estimates the impact of GM crop adoption on net returns. The results showed that the yields of GM crop farmers $(4,850 \mathrm{~kg} / \mathrm{ha})$ were significantly higher than those of the non-GM crop farmers $(3,610 \mathrm{~kg} / \mathrm{ha})$ and there was a significant welfare effect ( $\mathrm{PhP} 43.48$ million) of using GM crop among farmers. James (2010) stated that the first 500 million GM crop hectares in 2005 took 10 years to reach, but only 5 years were needed to plant the second 500 million GM crop hectares (a total of 1 billion GM crop hectares) in 2010.

Fourth, this paper found that the evolutionary loss of GM crops is an aggregated ecological loss through the evolutionary mechanism. Also, this paper is one of the first to establish models to prove the reason why its existence. Fifth, this paper found that small ecological loss would develop into substantial evolutionary loss and might result in crop species rapidly becoming purebred. So the sustainability of an ecosystem's biomass might not exist by the impact of the GM crop's economic value regardless of considering its ecological or evolutionary loss or not. Very few studies focus on the relationship between the ecological loss of GM crops and its evolutionary loss, and how the relationship affects crops. Hence, this paper builds models to fill this research gap. Craft and Simpson (2001) used two models of competition between differentiated products to derive the value of biodiversity for use in new product development, and found the private value of marginal species (as biodiversity) is small, and its social value could be very model-dependent and parameter-specific. However, these findings would undervalue biodiversity, due to the static models and negligible nonmarket value of biodiversity. The Secretariat of the Convention on Biological Diversity (2010) shows that the promotion of superior breeds (like GM crop) would reduce biodiversity.

Magg et al. (2001) found greater European corn borer larval mortality observed for GM maize (84.6\% after 4 days) when compared to non-GM maize (50.4\% after 4 days). 
Jesse and Obrycki (2000) proved that GM corn pollen naturally deposited on milkweed in a corn field (lethal effect) cause significantly higher mortality of monarch butterflies $(20 \pm 3 \%$ at $48 \mathrm{~h})$ than with no pollen $(3 \pm 3 \%$ at $48 \mathrm{~h})$ or with non-GM corn pollen $(0 \%)$. Hilbeck et al. (1998) proved that the mortality rate for chrysopid larvae raised on GM corn-fed prey was $62.25 \pm 5.97 \%$ compared with $36.88 \pm 4.57 \%$ when raised on non-GM corn-fed prey.

Last but not least, this paper simulated the impact of the value of GM crops due to identity preservation, improvement in planting technology and biotechnology, climate change, and conservation activities. Therefore, this paper fills another significant research gap as there is a lack of studies on the impact of the value of GM crops by the change of external factors. Specifically, this paper selected and observed the changes in external factors to understand how that related to the value of GM crops. The impacts on the value of GM crops are also considered.

\section{Conclusions}

This paper introduces optimal control models and numerical analysis to analyze the value of GM crops, seen as the sum of economic value, and ecological, and evolutionary loss. In the FGM model, which does not consider the value of biomass, a profitmaximizing farmer plant more GM crops. However, even the slightest loss of biomass caused by GM crops in the initial stage may become significant following the evolution mechanism. Furthermore, the biomass of the crop, pest, and ecosystem worsens by identity preservation, improvement in planting technology and biotechnology, and climate change in the FGM and GGM model. In the GGM model, which takes into consideration the value of biomass, the welfare-maximizing government plants the GM crop. Moreover, the social welfare could be improved by identity preservation, the improvement in planting technology and biotechnology, and biodiversity conservation activities.

Based on the simulation results, our conclusions are as follow. First, a GM crop raises not only the mortality of its natural enemies and species on the same food chain or ecosystem, as reported by previous studies, but also causes the ecological loss resulting from monoculture of the GM crop and competition between GM and non-GM crops, as well as evolutionary loss, which is ecological loss determined by the evolutionary mechanism. Second, the biomass of the ecosystem has been over-damaged by the introduction of GM crops, and market mechanisms alone cannot determine the efficient use of GM crops. Third, using GM crops for profit maximization induces species to become purebred quickly (Noailly, 2008). Thus, the impact of Genetically Modified Crop' value on the sustainability of an ecosystem's biomass might be significantly negative.

The several limitations of this study may provide useful ideas for future researchers. The main limitation of this study is the simplification of the GGM model for the simulations. As this paper takes into consideration of the value of a GM crop is highly simplified for the GM crops are not homologous. The future study could take the discussion on the different transgene or the different type of genetic modification could have influenced the value of the GM crop. Or as the government's target for ecosystem biomass, which should be its sustainability, could be utilized for a discussion of its impact on the government's behavior. Moreover, the model can consider the risk of GM crops, as a single pathogen could wipe out entire species and their predators (Martin, 2000). Capellesso et al. (2016) proved that GM crops increase environmental impacts without 
changing economic performance. Researchers can also study the impact of GM crops on the biomass of other species (as non-target insects). For example, they can study farm size for managing conventional corn-soybean rotation in a larger area than organic rotation (Lu et al., 2012; Delbridge et al., 2013). Finally, the bifurcation theory could be employed to assess the ecological and evolutionary value of GM crops, as it involves a complicated evolution mechanism and cannot be represented by an optimal control model.

\section{REFERENCES}

[1] Baral, N., Stern, M. J., Bhattarai, R. (2008): Contingent valuation of ecotourism in Annapurna conservation area, Nepal: implications sustainable park finance and local development. - Ecological Economics 66(2-3): 218-227. DOI: 10.1016/j.ecolecon. 2008.02.004.

[2] Bishop, J., Kapila, S., Hicks, F., Mitchell, P., Vorhies, F. (2008): Building Biodiversity Business. Shell International Limited and the International Union for Conservation of Nature: London, UK, and Gland, Switzerland. - International Union for Conservation of Nature, Switzerland. ISBN: 978-2-8317-1019-8.

[3] Blahova, P., Janda, K., Kristoufek, L. (2014): The perspectives for genetically modified Cellulosic Biofuels in the central European conditions. - Agricultural Economics 60(6): 247-259. EID: 2-s2.0-84903314070.

[4] Bradshaw, J. E. (2016): Plant Breeding: past, present, and future. - Springer: Berlin, Germany. ISBN: 978-3-319-23285-0.

[5] Brock, W. A., Xepapadeas, A. (2003): Valuing biodiversity from an economic perspective: a unified economic, ecological and genetic approach. - American Economic Review 93(5): 1597-1614. DOI: $10.1257 / 000282803322655464$.

[6] Brookes, G., Barfoot, P. (2015): Environmental Impacts of Genetically Modified (GM) Crop Use 1996-2013: Impacts on Pesticide Use and Carbon Emissions. - GM Crops \& Food 6(2): 103-133. DOI:10.1080/21645698.2015.1025193.

[7] Capellesso, A. J., Cazella, A. A., Schmitt Filho, A. L., Farley, J., Martins, D. A. (2016): Economic and environmental impacts of production intensification in agriculture: comparing transgenic, conventional, and agroecological maize crops. - Agroecology and Sustainable Food Systems 40(3): 215-236. DOI: 10.1080/21683565.2015.1128508.

[8] Chan, S., Maksimuk, A. V., Zhirnov, L. V., Nash, S. V. (1995): From Steppe to Store: The Trade in Saiga Antelope Horn. - TRAFFIC International, Cambridge, UK.

[9] Chern, W. S., Rickertsen, K., Tsuboi, N., Fu, T.-T. (2003): Consumer acceptance and willingness to pay for genetically modified vegetable oil and salmon: a multiple-country assessment. - AgBioForum 5(3): 105-112. Available online: http://agbioforum.org/v5n3/ v5n3a05-chern.pdf (accessed on 09/12/2017).

[10] Craft, A. B., Simpson, R. D. (2001): The value of biodiversity in pharmaceutical research with differentiated products. - Environmental and Resource Economics 18(1): 1-17. DOI: 10.1023/A:1011170024649.

[11] Delbridge, T. A., Fernholz, C., King, R. P., Lazarus, W. (2013): A whole-farm profitability analysis of organic and conventional cropping systems. - Agricultural systems 122: 1-10. DOI: 10.1016/j.agsy.2013.07.007.

[12] Flynn, K. J., Greenwell, H. C., Lovitt, R. W., Shields, R. J. (2010): Selection for fitness at the individual or population levels: modelling effects of genetic modifications in microalgae on productivity and environmental safety. - Journal of Theoretical Biology 263(3): 269-280. DOI: 10.1016/j.jtbi.2009.12.021.

[13] Garcia, S., Harou, P., Montagne, C., Stenger, A. (2009): Models for sample selection bias in contingent valuation: application to forest biodiversity. - Journal of Forest Economics 15(1-2): 59-78. DOI: 10.1016/j.jfe.2008.03.008. 
[14] Gregory, R. D., Willis, S. G., Jiguet, F., Voříšek, P., Klvaňová, A., Van Strien, A., Huntley, B., Collingham, Y. C., Couvet, D., Green, R. E. (2009): An indicator of the impact of climatic change on European bird populations. - PLoS ONE 4(3): e4678. DOI: 10.1371/journal.pone.0004678.

[15] Hilbeck, A., Baumgartner, M., Fried, P. M. (1998): Effects of transgenic bacillus thuringiensis corn-fed prey on mortality and development time of immature Chrysoperla Carnea (Neuroptera: Chrysopidae). - Environmental Entomology 27(2): 480-487. DOI: 10.1093/ee/27.2.480.

[16] Ives, A., Andow, D. A. (2002): Evolution of resistance to Bt crops: directional selection in structured environments. - Ecology Letters 5(6): 792-801. DOI: 10.1046/j.14610248.2002.00392.x.

[17] Jacobsen, S. E., Sørensen, M., Pedersen, S. M., Weiner, J. (2013): Feeding the world: genetically modified crops versus agricultural biodiversity. - Agronomy for Sustainable Development 33(4): 651-662. DOI:10.1007/s13593-013-0138-9.

[18] James, C. (2005): Global Status of Commercialized Biotech/GM Crops: 2005. - ISAAA: NY, USA. ISBN 1-892456-38-9.

[19] James, C. (2010): Global Status of Commercialized Biotech/GM Crops: 2010. - ISAAA Brief No. 42. ISAAA: Ithaca, NY.

[20] Jesse, L. C. H., Obrycki, J. J. (2000): Field deposition of Bt transgenic corn pollen: Lethal effects on the Monarch butterfly. - Oecologia 125(2): 241-248. DOI: 10.1007/ s004420000502.

[21] Jose, M., Yorobe, Jr., Cesar, B. Q. (2006): Economic impact of Bt corn in the Philippines. - The Philippine Agricultural Scientist 89(3): 258-267.

[22] Klümper, W., Qaim, M. (2014): A meta-analysis of the impacts of genetically modified crops. - PloS one 9(11): e111629. DOI: 10.1371/journal.pone.0111629.

[23] Kouser, S., Qaim, M. (2013): Valuing financial, health, and environmental benefits of Bt cotton in Pakistan. - Agricultural Economics 44(3): 323-335. DOI: 10.1111/agec.12014.

[24] Lu, Y., Jiang, K., Wu, Y., Guo, Y., Desneux, N. (2012): Widespread adoption of Bt cotton and insecticide decrease promotes Biocontrol services. - Nature 487(7407): 362-365. DOI: 10.1038/nature11153.

[25] Lusk, J., Daniel, M. S., Mark, D., Lusk, C. (2001): Alternative calibration and auction institutions for predicting consumer willingness to pay of Nongenetically modified corn chips. - Journal of Agricultural and Resource Economics 26(1): 40-57. Available online: http://www.waeaonline.org/jareonline/archives/26.1\%20-

\%20July\%202001/JARE,Jul2001,pp40, Lusk.pdf (accessed on 09/12/2017).

[26] Magg, T., Melchinger, A. E., Klein, D., Bohn, M. (2001): Comparison of Bt maize hybrids with their non-transgenic counterparts and commercial varieties for resistance to European corn borer and for agronomic traits. - Plant Breeding 120(5): 397-403. DOI: 10.1046/ j.1439-0523.2001.00621.x.

[27] Mainwaring, L. (2001): Biodiversity, biocomplexity, and the economics of genetic dissimilarity. - Land Economics 77(1): 79-83. DOI: 10.2307/3146982.

[28] Marra, M., Pannell, D. J., Ghadim, A. A. (2003): The economics of risk, uncertainty, and learning in the adoption of new agricultural technologies: where are we on the learning curve? - Agricultural systems 75(2): 215-234. DOI: 10.1016/s0308-521x(02)00066-5.

[29] Martin, S. W. (2000): Crop strength through diversity. - Nature 406(6797): 681-682. DOI: $10.1038 / 35021152$.

[30] Martin-Lopez, B., Montes, C., Benayas, J. (2007): Influence of user characteristics on valuation of ecosystem services in Doñana natural protected area (South-West Spain). Environmental Conservation 34(3): 215-224. DOI: 10.1017/s0376892907004067.

[31] Matero, J., Saastamoinen, O. (2007): In search of marginal environmental valuations ecosystem services in Finnish forest accounting. - Ecological Economics 61(1): 101-114. DOI: $10.1016 /$ j.ecolecon.2006.02.006. 
[32] McDowell, N. G., Beerling, D. J., Breshears, D. D., Fisher, R. A., Raffa, K. F., Stitt, M. (2011): The interdependence of mechanisms underlying climate-driven vegetation mortality. - Trends in Ecology \& Evolution 26(10): 523-532. DOI: 10.1016/ j.tree.2011.06.003.

[33] Mutuc, M., Rejesus, R. M., Yorobe Jr., J. M. (2013): Which farmers benefit the most from Btcorn adoption? estimating heterogeneity effects in the Philippines. - Agricultural Economics 44(2): 231-239. DOI:10.1111/agec.12006.

[34] Nehring, K., Puppe, C. (2002): A theory of diversity. - Econometrica 70(3): 1155-1198. DOI: $10.1111 / 1468-0262.00321$.

[35] Noailly, J. (2008): Coevolution of economic and ecological systems: an application to agricultural pesticide resistance. - Journal of Evolutionary Economics 18(1): 1-29. DOI: $10.1257 / 000282803322655464$.

[36] Polasky, S., Solow, A. R. (1995): On the value of a collection of species. - Journal of Environmental Economics and Management 29(3): 298-303. DOI: 10.1006/ jeem.1995.1048.

[37] Qaim, M., Zilberman, D. (2003): Yield effects of genetically modified crops in developing countries. - Science 299(5608): 900-902. DOI: 10.1126/science.1080609.

[38] Raymond Park, J., McFarlane, I., Hartley Phipps, R., Ceddia, G. (2010): The role of transgenic crops in sustainable development. - Plant Biotechnology Journal 9(1): 2-21. DOI: $10.1111 / j .1467-7652.2010 .00565 . x$.

[39] Sanvido, O., Romeis, J., Bigler, F. (2007): Ecological Impacts of Genetically Modified Crops: Ten Years of Field Research and Commercial Cultivation. - In: Fiechter, A., Sautter, C. (eds.) Green Gene Technology. Advances in Biochemical Engineering/Biotechnology 107. Springer; Berlin, Heidelberg, Germany. ISBN: 978-3540-71323-4.

[40] Siikamaki, J., Layton, D. F. (2007): Discrete choice survey experiments: a comparison using flexible methods. - Journal of Environmental Economics and Management 53(1): 122-139. DOI: 10.1016/j.jeem.2006.04.003.

[41] Stanger, T. F., Lauer, J. G. (2006): Optimum plant population of Bt and non-Bt corn in Wisconsin. - Agronomy Journal 98(4): 914-921. DOI: 10.2134/agronj2005.0144.

[42] The International Service for the Acquisition of Agri-biotech Applications (2016): Global Status of Commercialized Biotech/GM Crops: 2016. - ISAAA: NY, USA. ISBN 978-1892456-66-4.

[43] The Law Library of Congress (2014): Restrictions on Genetically Modified Organisms: Argentina, Belgium, Brazil, Canada, China, Egypt, England and Wales, European Union, France, Germany, Israel, Italy, Japan, Lebanon, Mexico, Netherlands, New Zealand, Norway, Russian Federation, South Africa, South Korea, Sweden, United States. International Protocols, Bibliography. Available online: https://www.loc.gov/law/help/ restrictions-on-gmos/restrictions-on-gmos.pdf (accessed on 09/12/2017).

[44] The Secretariat of the Convention on Biological Diversity (2010): Global Biodiversity Outlook 3. - Montréal (http://gbo3. cbd. int/) Phil. Trans. R. Soc. B (Vol. 9).

[45] United Nations (2010): Global Biodiversity Outlook 3. - United Nations: NY, USA. ISBN: 978-9-292-25220-5.

[46] Vatn, A., Bromley, D. W. (1994): Choices without prices without apologies. - Journal of Environmental Economics and Management 26(2): 129-148. DOI: 10.1006/ jeem.1994.1008.

[47] Weitzman, M. L. (1998): The Noah's ark problem. - Econometrica 66(6): 1279-1298. DOI: $10.2307 / 2999617$.

[48] World Resources Institute; the World Conservation Union; United Nations Environment Program (1992): Global Biodiversity Strategy: Guideline for Action to Save, Study and Use Earth's Wealth Sustainably and Suitably. - World Resources Institute: Washington, D. C. USA. ISBN: 0-915825-74-0. 
[49] Yi, Z. F., Cannon, C. H., Chen, J., Ye, C. X., Swetnam, R. D. (2014): Developing indicators of economic value and biodiversity loss for rubber plantations in Xishuangbanna, southwest China: a case study from Menglun township. - Ecological Indicators 36: 788797. DOI: 10.1016/j.ecolind.2013.03.016. 